\title{
気候差分ダウンスケーリング法による \\ 関東・中部山岳域の確率論的気候変化予測 \\ PROBABILISTIC CLIMATE CHANGE PROJECTION IN KANTO AND JAPAN ALPS REGIONS USING INCREMENTAL DYNAMICAL DOWNSCALING
}

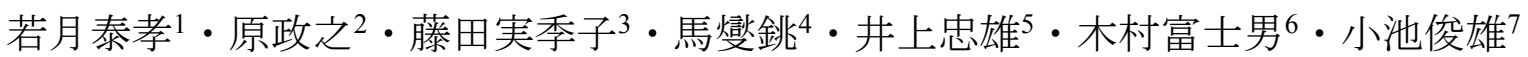 \\ Yasutaka WAKAZUKI, Masayuki HARA, Mikiko FUJITA, Xieyao MA, Tadao INOUE, \\ Fujio KIMURA and Toshio KOIKE \\ 1正会員 理博 筑波大学助教 （テ305-8577 茨城県つくば市天王台1-1-1） \\ 2非会員 理博 埼玉県環境科学国際センター主任 （テ347-0115 埼玉県加須市上種足914） \\ 3 非会員 理博 海洋研究開発機構技術研究員（广236-0001 神奈川県横浜市金沢区昭和町3173-25） \\ 4非会員 理博 海洋研究開発機構主任研究員（干236-0001 神奈川県横浜市金沢区昭和町3173-25） \\ 5 非会員 理博 元海洋研究開発機構（广236-0001 神奈川県横浜市金沢区昭和町3173-25） \\ 6非会員 理博 筑波大学研究員（テ305-8577 茨城県つくば市天王台1-1-1） \\ 7フェロー会員 工博 東京大学教授 大学院工学系研究科（勇113-8656 東京都文京区本郷7-3-1）
}

The incremental dynamical downscaling and analysis system (InDDAS) which has been developed from the pseudo-global-warming method by appending partial functions was applied for a probabilistic regional scale climate change projection with the target regions of Kanto and Japan Alps. In InDDAS, the most reliable future state was projected by a regional climate model (RCM) simulation with an ensemble mean among the climatological increments of multiple general circulation model (GCM) simulations. In addition, the uncertainty of the future projections is estimated by RCM simulations with the multi-modal statistical increments calculated by the singular vector decomposition of the multiple GCMs. An increase of rainfall with the change ratio of 7-16\% was projected in Kanto region, where the most reliable value was $10 \%$. The change ratios of the vicinity quantiles of extreme rainfall was projected to be larger than that of rainfall and was almost the same as the value explained by the Clausius-Clapeyron effect.

Key Words : Climate change projection, Regional Climate Model, Probabilistic Projection

\section{1. はじめに}

地域スケールの気候変化予測は，気候変化の影響評価 および適応策の検討のために，その必要性が近年急激に 高まっている. IPCC ${ }^{1)}$ は，温暖化によって全球規模での 強雨化を予測している. また，大気の熱・水循環の変化 に伴い，乾燥化や降水量の増加など，地域ごとに異なる 水環境の変化が起こることを示唆している.

一般的に，大気・海洋・地表面過程などの物理素過程 をモデル化した全球気候モデル(GCM)を用いて， $\mathrm{CO}_{2}$ 排 出量などの放射に関わる強制力を与えた大規模数值シ ミュレーションで将来を予測する。しかし，GCMによ る予測は計算負荷が大きいために解像度を粗くせざるを 得ず，地域スケールの適応研究には不向きである. そこ
で，特定地域のみを高解像度化するダウンスケーリング (DS)が行われる. DS は統計的DS と領域気候モデル (RCM)を用いた力学的DSがある. 統計的DSは定量化に 向いており，多くの研究がなされている (Wilby et al.2)ほ か）。ただし，観測が少なく経験則の不確実性が大きい 場合には明らかに不向きである. 力学的DSは，物理的 に現象を計算していることから，統計的DSでの経験則 の変化などを心配する必要はない. 力学的DSでも誤差 を生じるが，その潜在的利用価値は高いといえる，たと えば, 21 世紀後半の日本周辺の大気環境を予測する RCM実験が数多くなされてきた（Wakazuki at al. ${ }^{3)}$ ほか）。 力学的DSは, 全球気候モデルの結果を側面境界条件 として特定領域の高解像のRCM実験を行う. その際, GCMが持っているバイアスをRCM実験は概ね引き継ぐ 性質を持っており, RCMの結果に影響を与える. そこ 
で，このバイアス問題を解決するために，力学的DSに おける近似手法が開発された. Sato et al. ${ }^{4)}$ ，Kimura and Kito ${ }^{5}$ は，疑似温暖化手法(Pseudo-global-warming Method (PGW 法))を開発し, Misra and Kanamitsu' ${ }^{6}$ はanomaly nestingという方法を開発した。いずれの方法も客観解析 データとGCMから得られる情報を有機的に結合して， バイアスの小さなRCMの境界条件を作成する.

気候変化予測には大きな不確実性がある，温室効果ガ ス排出シナリオに対する不確実性，GCMやRCMのモデ ルのばらつきに起因する不確実性である.この中で, GCMの予測の不確実性は定量化して扱うことができ， かつ無視できない大きさを持つ.したがって，DSにお けるGCMの予測の不確実性を考慮し, 確率論的に地域 スケールの気候変化を予測する必要がある。確率論的気 候変化予測の取り組みは，近年べイズ推定法を中心とし て取り組まれている（Tebaldi et al.7)ほか）。

一方で, RCM実験では, 豪雨などが物理的に再現で きることが期待されるが，そのためには数 $\mathrm{km}$ 解像度で 実験しなければならず，RCM実験の計算負荷は大きく なる.よって，多くのGCM実験結果を利用して予測の 不確実性を扱う場合，それに合わせてRCMの実験を数 多く行うことが困難になる．本研究では，これらの諸問 題を解決するために，PGW法の発展的な手法として開 発されている気候差分ダウンスケーリング法の開発の現 状を2章で簡潔に紹介する。また，関東と中部山岳域を 対象として実施された高解像度領域気候変化予測実験を 3章で紹介し，その結果を用いた確率論的な解析につい て4章で紹介する.

\section{2. 気候差分ダウンスケーリング法}

PGW法は，GCMによる気候変化予測をタイムスラ イス法でダウンスケーリングする手法の一種であり，現 在気候と将来気候の $2 つ 0$ 数值実験を実施することにな る。一般的な領域気候実験では，GCMによる気候実験 結果を側面境界条件として利用するため, 現在気候実験 の結果はGCMが持つバイアスの影響を反映して，比較 的大きなバイアスをもつ.一方，PGW法では，現在気 候実験において客観解析データを側面境界条件として利 用するため，バイアスが比較的小さくなるというメリッ トがある。ただし，GCMが作り出すバイアスは大幅に 軽減するが， RCMが作り出すバイアスは残るため，バ イアス補正を後に施す必要がある。将来気候実験での側 面境界条件は，客観解析データにGCMで見積もられた 平均気候差分が上乗せされて作成される. 上乗せされる 平均気候差分は，空間分布をもつジオポテンシャル高度， 気温, 風速, 表面温度 (地表面温度や海面水温) であり, 対象年間で平均した月ごとのデータとする．また，Hara et al. $^{8}$ は，相対湿度を一定としている. PGW法では，
GCMで計算される情報のうち, 各月の平均気候差分の み信用できる情報であると仮定しており，GCMで計算 される相対湿度の気候変化, 年々変動の気候変化, 擾乱 などの短周期変動の気候変化の情報は用いない. しかし， 平均気候差分のみを適用することで，様々な不整合が生 じるため，予測の信頼性を下げる原因になっている．例 えば，側面境界から計算領域に入ってくる台風に着目す ると, 将来気候の台風は現在気候と同じ位置同じタイミ ングで，側面境界から入ってくることになる．そこで著 者らは，PGW法を高度化することで気候差分ダウンス ケーリング法 (Incremental Dynamical Downscaling and Analysis System (InDDAS)) を開発している. PGW法で はGCMの平均気候差分しか扱っていないが，InDDASで はさらに高次のGCMの気候変化要素も扱う。さらに, GCMの予測の不確実性をDSに組み込むことができる.

Wakazuki ${ }^{9}$ はGCMが予測する水蒸気量の平均気候差分 の取り込み手法を開発した．PGW法で相対湿度を一定 としているのは，湿潤環境下で相対湿度の差分を扱った 場合，不自然な過飽和が頻発して予測が破たんするため である，そこで，相対湿度にかわって，比較的良好に正 規性近似ができる修正相対湿度を導入し，過飽和問題を 解決した. 温暖化時の相対湿度は全球スケールの観点か らは大きく変化しないと予測されるが，地域スケールや 陸域の大気下層では変化が起こる可能性が示唆される $\left(\mathrm{IPCC}^{1}\right)$ ほか）。このため，水蒸気量の変化成分の導入 は領域気候変化予測に影響を与える.

Wakazuki et al. ${ }^{10)}$ は，GCMが予測する月平均量の年々 変動の気候変化を扱う手法を開発した。この方法は, 客 観解析データがもつ年々変動パターンを特異值分解し, 説明可能な変動パターンをGCMから抽出した後, それ ぞれのモードの現在から将来への振幅の増幅を客観解析 に施すものである. 本論では，詳細の説明は省略する. 冬型の気圧配置の出現の程度や，梅雨前線の出現の度合 いがGCMで変化すると予測された場合に，その情報が RCMによる計算結果に反映される.ただし， RCMの計 算結果に劇的な結果の違いを生じさせるものではない. InDDASではPGW法同様に，擾乱や短周期変動の気候変 化を扱っておらず，RCM実験の境界条件においては， 将来気候の低気圧は現在気候のそれと同じである。短周 期変動の気候変化の扱いについては，将来の開発課題で あり, 特に極端事象の気候変化について定量するために は必要であり, 現時点ではPGW法もInDDASも極端事象 の気候変化を定量的に扱うのは問題がある.

Kawase et al. ${ }^{11)}$ は，PGW法において選択した7つの GCMの気候差分を上乗せした7つのRCM将来気候実験の 結果を平均した結果は，7つのGCMの平均気候差分を用 いた1つのRCM将来気候実験の結果と概ね等しくなるこ とを示した. GCMの気候差分は特定のGCMから算出さ れたものである必要はなく，GCMの情報をもとに作成 された平均などの統計量でも問題ないことが示された. 
平均気候差分を上乗せしたRCM実験結果は, GCMの予 測の不確実性を考慮した上で，最も信じ得る将来気候を 算出する（ただし，バイアス補正は必要である）.

そこで，Wakazuki and Rasmussen ${ }^{12}$ は，気候差分の統計 量を用いることで，平均像だけでなく不確実性の幅を定 量的に見積もる手法を開発した. 12か月分の月平均気候 差分を複数 $\mathrm{GCM}$ 個並べ，平均気候差分とそこからの偏 差に分ける．偏差成分を特異值分解することで，GCM 間のばらつきのパターン（特異ベクトルとして抽出され る）が得られる，それぞれのモードの変動パターンに正 と負の標準偏差を掛け合わせることで，1つのモードの 不確実性パターンに対して3種類の気候差分を作成する ことができる． 3 種類の気候差分 $\Delta \mathbf{X}^{(0)}$ （アンサンブル 平均),$\Delta \mathbf{X}^{(+)}$(正偏差),$\Delta \mathbf{X}^{(-)}$(負偏差) は,

$$
\left(\begin{array}{l}
\Delta \mathbf{X}^{(0)} \\
\Delta \mathbf{X}^{(+)} \\
\Delta \mathbf{X}^{(-)}
\end{array}\right)=\left(\begin{array}{c}
\overline{\Delta \mathbf{X}} \\
\overline{\Delta \mathbf{X}}+\mathbf{S} \mathbf{V}^{\mathrm{T}} \boldsymbol{\Sigma} \\
\overline{\Delta \mathbf{X}}-\mathbf{S} \mathbf{V}^{\mathrm{T}} \boldsymbol{\Sigma}
\end{array}\right)
$$

と表現される，ここで $\overline{\Delta \mathbf{X}}$ は平均気候差分， $\mathbf{S}$ は標準偏 差， Vは特異ベクトル， $\boldsymbol{\Sigma}$ は $\mathbf{X}$ の標準化における標準偏 差である.1つのモードにつき3つの気候差分の統計量が 作成され，1，2，3..Mモードに対して3，5，7 ... $(2 \times \mathrm{M}+1)$ 個の気候差分の統計量が作成され，それぞれの 気候差分を用いた将来気候実験が実施できる．上位数 モードでGCMの不確実性が表現できる場合, 多量の GCMサンプルがあった際にRCMの計算量を劇的に減少 させることができる.

本研究では, Phase 3 of the Coupled Model Intercomparison Project (CMIP3) $の$ Special Report on Emission Scenarios (SRES) A1B (Meehl et al. ${ }^{13)}$ )に基づく18 個のGCM（表-1）を利用した. 現在気候での気温場, アンサンブル平均(EM), 第1モード正負, 第2モード正 負の気温の気候差分を図-1に示す，ただし，現在気候を 1980～2009，将来気候を2070～2099とした．EMは3度程 度の昇温を予測している。，一方，第1モード正は4度，第 1モード負は2.5度程度の昇温となっており, GCM の予測 のばらつきのうち昇温量の大きさの違いは，最も大きな 変動要素として第1モードに抽出される. 第2モード以下 は温度の違いは大きくないが, 気温以外の大気循環のば らつきが顕著となる（図略）。このようにInDDASは， PGW法からの様々な高度化技法をパーツとして組み込 むことで発展している. 本研究では, これまで開発され たパーツを全て組み込んで, 関東・中部山岳域の高解像 領域気候実験を行った結果を紹介寸る.

表-1 利用した全球気候モデル一覧（CMIP-3，SRES A1B）

\begin{tabular}{|c|c|c|}
\hline BCCR-BCM2.0 & CGCM3.1(T47) & CGCM3.1(T63) \\
\hline CNRM-CM3 & CSIRO-Mk3.0 & CSIRO-Mk3.5 \\
\hline GFDL-CM2.0 & GFDL-CM2.1 & FGOALS-g1.0 \\
\hline INGV-SXG & NM-CM3.0 & IPSL-CM4 \\
\hline MIROC3.2(hires) & IROC3.2(medres) & ECHAM5/MPI-OM \\
\hline MRI-CGCM2.3.2 & CCSM3 & UKMO-HadCM3 \\
\hline
\end{tabular}
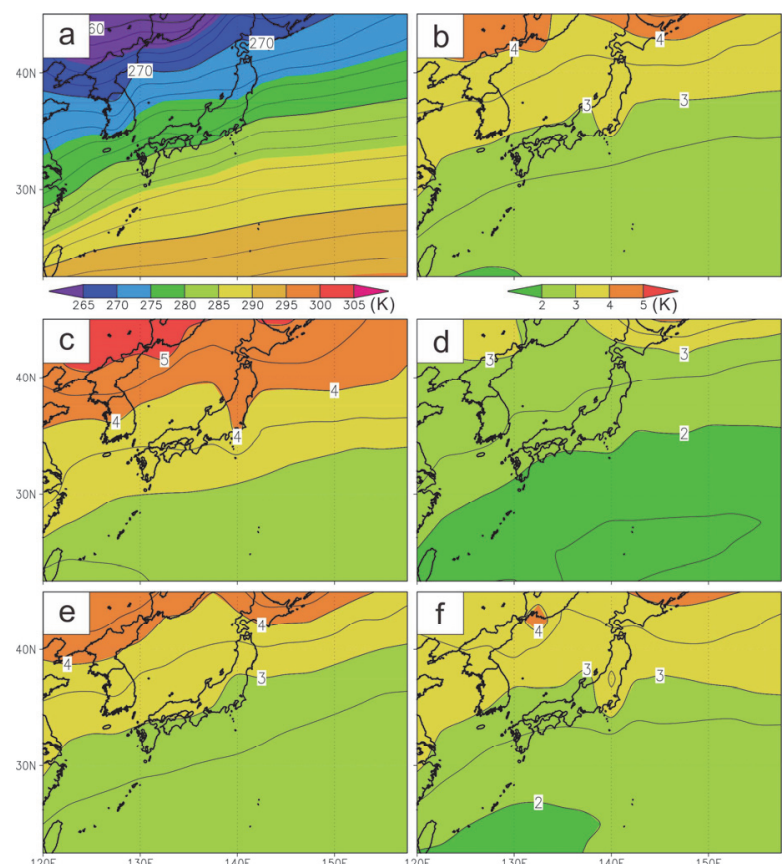

図-1 RCMで計算された 1 月の $1000 \mathrm{hPa}$ の平均気温の分布図. (a) は現在気候，(b-f)は18のGCMを用いて気候差分ダウンス ケーリング法で見積もった平均気候差分で，(b) アンサ ンブル平均，(c) 第1モード正，(d) 第1モード負，(e) 第2 モード正，(f) 第2モード負.

\section{3. 高解像気候变化予測}

表-2に本研究でのRCM実験の設定を, 図-2に計算領 域を示す. 3 重領域を設定し一方向ネスティングを行う. 格子間隔は $24 \mathrm{~km}, 6 \mathrm{~km}, 2 \mathrm{~km}$ である. 31年分の実験を並列 で行った．実験は9月1日に始まり，翌年の11月1日に終 了寸る. 最初の 2 胙は立ち上げ期間と考え, 解析から 除外した。 RCMとしてWRF (Weather Research and Forecasting) バージョン3.3.1 (Skamarock et al. ${ }^{14)}$ ) を利用 しており，陸面過程はNoah-LSMスキームで計算されて いる．表-2の鉛直格子設定や物理スキームは，降水の強 度別の頻度分布（特に強雨の頻度）が観測と近くなるよ うに選択されたものである.

$6 \mathrm{~km}$ 解像度実験では，第2モードまでの気候差分を扱 い，5つのRCM将来気候実験を実施した。計算負荷の著 しく大きい $2 \mathrm{~km}$ 解像度実験は, EM実験のみとした. 図3 は， $6 \mathrm{~km}, 2 \mathrm{~km}$ 解像度実験での降水量分布およびその気 候変化量を示す． $6 \mathrm{~km}$ と $2 \mathrm{~km}$ の実験間で目立つような特 徵の違いはないものの, $2 \mathrm{~km}$ 実験では, その地形の詳細 さに対応して, より細かい空間分布が再現されている. 中部山岳域および日本海・太平洋沿岸域で降水量は多い. 気候変化量は日本海と太平洋沿岸域で降水量が顕著に増 加すると予測される. 特に冬季に日本海沿岸域で, 夏季 に太平洋沿岸域を中心とした広域で降水量増加が顕著で ある. 春季と秋季の変化量は大きくない（図略）。いず れも, 昇温に伴う大気下層の水蒸気量増加およびそれに 
ともなう大気の成層不安定化が関係していると思われる. 図-4に降水量の変化比，1時間降水量の年3位值の変化 比，24時間降水量の年3位值の変化比を示している. こ こで，将来の值を現在の值で割った值を変化比とする. 極值近傍值を代表して3位值を紹介寸る．温暖化に伴い 降水量は増加している．変化比は，1.10程度である．関 東平野付近では，2.7度程度の昇温であり，ClausiusClapeyron(CC)効果を考慮すると（1度の昇温につき7\%程 度の増加に相当する）1.19程度の変化比になるが，予測 はそれよりも小さな変化となっている. 3位值の分布図 ではランダムな斑点模様が浮き出るが，これは実験年数 が少ないことによって生じるサンプリング誤差によるも のと考えられる. 3位值の変化比は降水量の変化比より も大きく, 関東平野では1.15〜1.20程度の変化となる. 降水量の変化比よりも極值近傍值の変化比の方が大きい. このように，極值の変化比がCC効果に近いという特徵 は, 近年の研究でも指摘されており, 概ね妥当な結果と いえる $\left(\mathrm{IPCC}^{1)}\right)$ ．なお，他の上位值でも概ね似た傾向 がみられた。

\section{表-2大気モデルおよび予測実験の設定.}

\begin{tabular}{|c|c|}
\hline \multicolumn{2}{|r|}{ 実験設定 } \\
\hline モデル & WRF version 3.3 .1 \\
\hline 実験年 & 1979-1980 ～ 2009-2010 (31年) \\
\hline 実験期間（1年実験） & 9月1日 - 翌年11月1日 \\
\hline 解析期間 & 11月1日- 翌年11月1日 \\
\hline 境界値データ & ERA-Interim $\left(\right.$ Dee et al. $\left.{ }^{15)}\right)$ \\
\hline \multicolumn{2}{|r|}{ 格子情報 } \\
\hline 領域 & 図-1 \\
\hline 格子間隔 (領域 $1,2,3$ ) & $24 \mathrm{~km}, 6 \mathrm{~km}, 2 \mathrm{~km}$ \\
\hline 格子数 (領域1,2,3) & $112 \times 91 \times 37,125 \times 97 \times 37,189 \times 174 \times 37$ \\
\hline \multicolumn{2}{|r|}{ 物理過程 } \\
\hline 雲物理過程 & Double-moment 6-class scheme \\
\hline 放射 & RRTMG scheme \\
\hline 陸面過程 & Noah land surface model (on-line) \\
\hline 境界層乱流 & $\begin{array}{c}\text { Mellor-Yamada Nakanishi and Niino } \\
\text { Level 2.5 PBL }\end{array}$ \\
\hline 積雲対流 & Kain-Fritsch scheme (領域 1) \\
\hline 都市効果 & なし \\
\hline
\end{tabular}

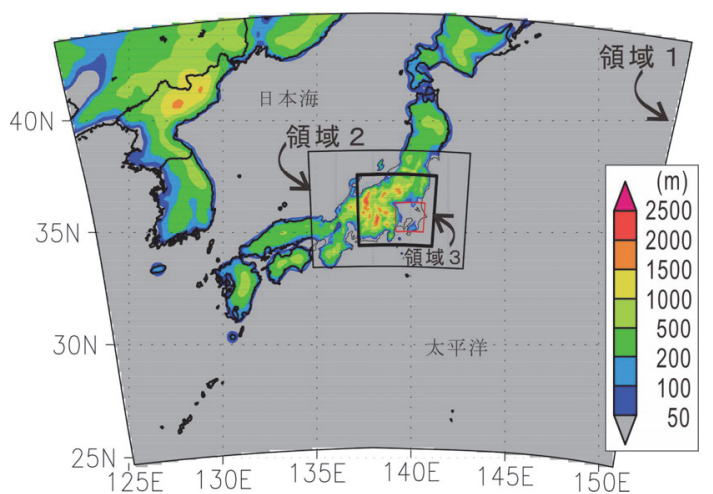

図-2ＲCMIよよる気候実験の領域（領域1〜3），およびモデル 標高. 赤枠は図-5, 図-6で用いる解析領域.

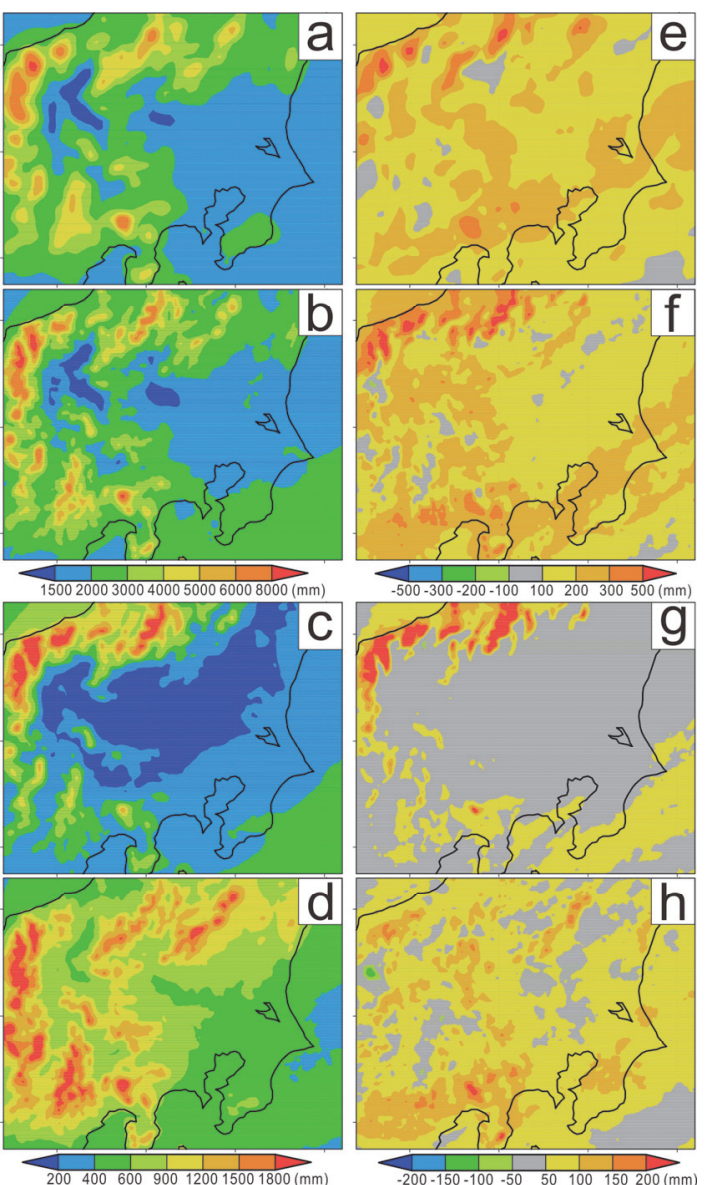

図-3（a， b， c， d）現在気候実験での降水量, (e, f, g, h) アンサンブル平均実験での降水量の変化量. (a, b, e, f) は年降水量. (c, g) は12 2月の降水量. (d, h) は6 8月の降水量. (a, e) は $6 \mathrm{~km}$ 解像度の結果で, それ以外は $2 \mathrm{~km}$ 解像度の結果.

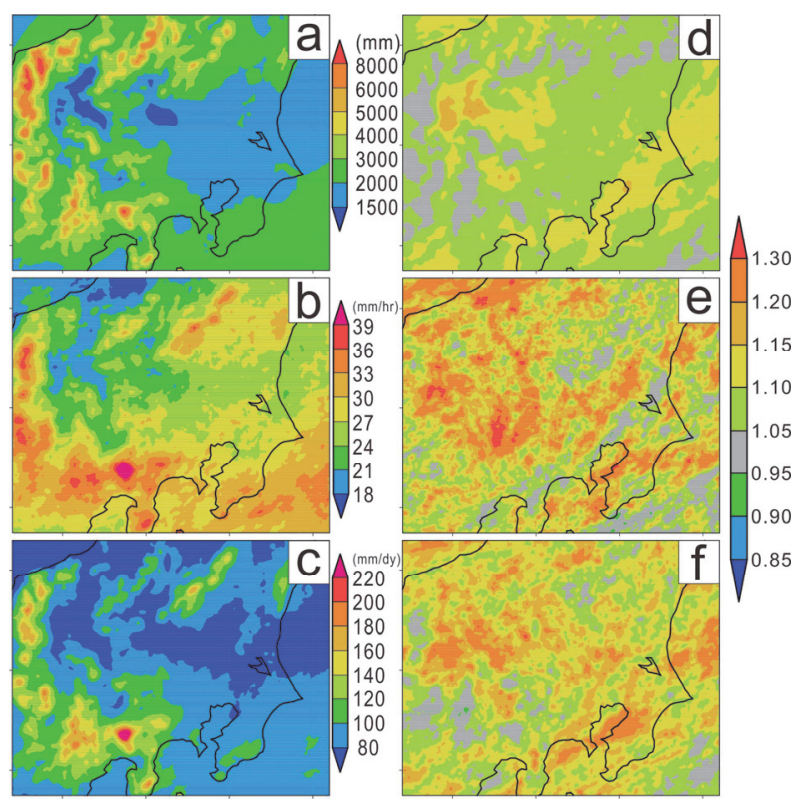

図-4 RCMで計算された降水予測分布.（a， d) 年降水量，(b, e） 1時間降水量の年3位值，（c，f）24時間降水量の年3 位值. (a, b , c) は現在気候, (d, e, f) は気候変化比. いずれも2km解像度実験の結果. 


\section{4. 気候変化予測の不確実性}

気候変化予測の不確実性を定量化するために，気候差 分の第2モードまでの正負の摂動を用いたRCM将来予測 実験を $6 \mathrm{~km}$ 解像度で実施した。第1モードは図-1に示し たように昇温量の違いが顕著に現れる. 図-5は季節別の 気温と降水量の変化で，第1モードの正負のRCM実験で 結果が大きく異なっていることを示している．冬季の降 水量は, 昇温が大きいほど降水量の変化比も大きくなっ た. 一方，夏季の降水量は，昇温量が大きくなれば降水 量がより多く増加するという線形関係が満たされていな い月があり (8, 9月)，昇温に対する応答の非線形性が 顕著であることを示している，同様に，各月の上位3位 值でも，非線形応答が特に8,9月に見られる.

InDDASでは，マルチモード気候差分を用いたRCM実 験の結果を用いて, 将来の状態の確率情報を作り出すこ

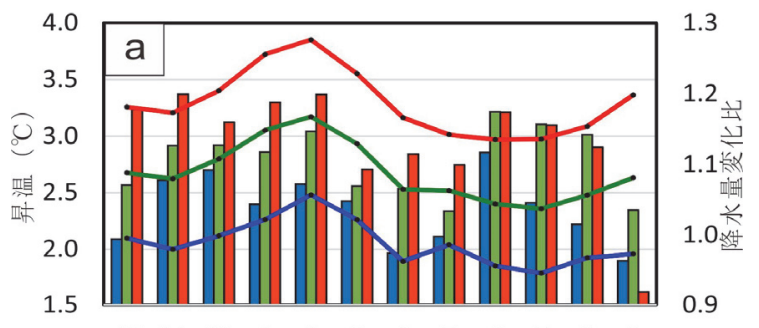

$\begin{array}{llllllllllll}10 & 11 & 12 & 1 & 2 & 3 & 4 & 5 & 6 & 7 & 8 & 9\end{array}$

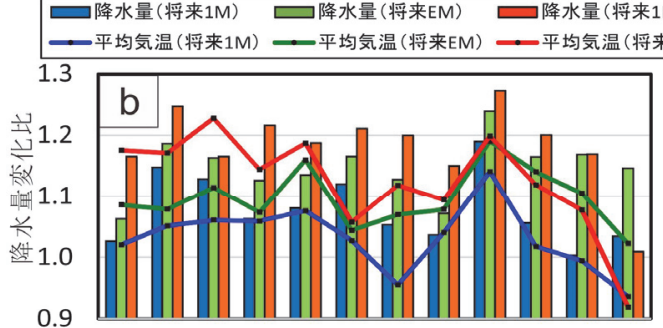

$\begin{array}{llllllllllll}10 & 11 & 12 & 1 & 2 & 3 & 4 & 5 & 6 & 7 & 8 & 9\end{array}$

ए1時間降水量3位值(将来1M) 1 1時間降水量3位值(将来EM)

$\square$ 1時間降水量3位值(将来1P) -24時間降水量3位値(将来EM)

-24 時間降水量3位值(将来1M) -24 時間降水量3位値(将来1 P)

図-5 (a)RCMで計算された平均 $2 m$ 気温の変化量（線づラフ）と 降水量変化比（棒グラフ）の月別值. $1 \mathrm{P}, 1 \mathrm{M}, 2 \mathrm{P}, 2 \mathrm{M}$ は モード番号と正 $(P)$ 負 $(M)$ を表現した省略記号. (b) 1時 間降水量と24時間降水量の3位值の変化比. $6 \mathrm{~km}$ 実験解像 度の結果で，図-2の赤枠領域の平均.

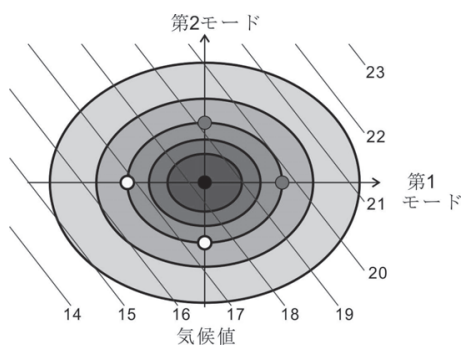

図-6 2モードまでの計算結果から確率值を算出する概念図. 5 つの丸印はRCMの結果から計算された気候値．等値線 （直線）はそれらの值を重回帰分析で求めた等気候値線。 影は多変量確率密度値。

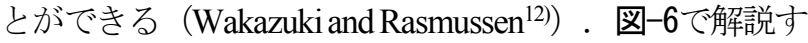
る. 1つのモードに対して3つの実験結果が与えられるが, 正規性を仮定すると，それらの值に相当する多変量確率 密度值が決まる，複数モードに拡張した場合は，各モ一 ドの直交性を仮定して，同様に多変量確率密度值を推定 する. 次に気候差分に対するRCMの結果の線形応答を 仮定して，抽出された気候值（2モードに対して5つ）の 等值直線を重回帰分析で決める. 最後に, 多変量空間の 確率密度值を等気候值毎に積分することで1次元確率密 度值に変換すると，図-7に示されるように，GCMの予 測の不確実性を考慮した将来の気温と降水量の確率密度 分布を描くことができる．図-7の結果（バイアス補正が かけられていない）は，昇温と降水量増加は間違いない ものの，大きな予測の不確実性があることを示している。 なお，より確からしい確率分布を推定するには，第2 モードよりもさらに下位のモードまで計算する必要があ り，標準偏差がより大きくなる可能性がある. 下位の気 候差分には昇温量のばらつきの情報よりも循環場のばら

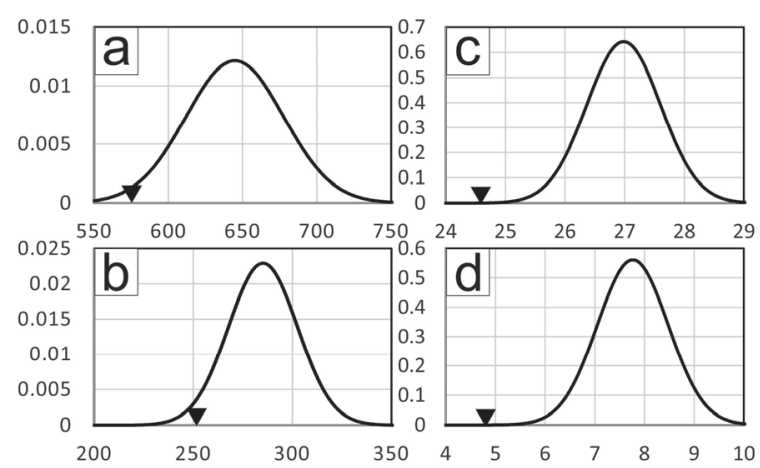

図-7 図-2の赤枠領域（関東平野）で平均したRCMで計算され た $(a, b)$ 降水量亡 $(c, d)$ 平均 $2 m$ 気温の将来の確率分布 （実線）。寻は現在気候実験の結果. (a, c) は6〜8月, (c, d) は12〜2月. $6 \mathrm{~km}$ 実験解像度の結果.

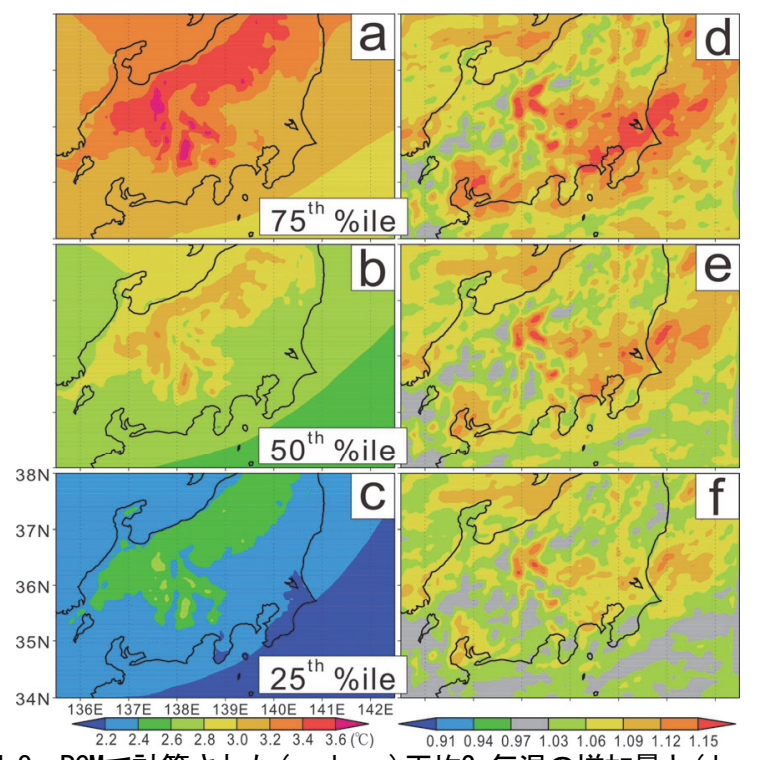

図-8 RCMで計算された $(a, b, c)$ 平均 $2 m$ 気温の増加量と (d, e f) 降水量の変化比. (a, d) 75 , (b, e) 50, （c, f） 25 パーセンタイル值の分布. $6 \mathrm{~km}$ 実験解像度の結果. 
つきの情報が多く含まれているために，特に降水量の変 化予測の不確実性評価に大きく影響を及ぼすことが推測 される.この方法を用いると，図-8に示されるような気 温と降水量の $25,50,75$ パーセンタイル值分布などを描く ことができる. 75パーセンタイルの気温の状態と75パー センタイルの降水量の状態は同時に出現するのではなく, あくまで要素ごとに值の小さいものから大きいものに並 べた時の值の分布図である. 関東の降水量予測には，比 で1.07〜1.16程度までの違いが予測されている.

\section{5. まとめ}

InDDASを用いて，関東および中部山岳域の大気環境 の気候変化を予測する領域気候数值実験を実施した. InDDASでは, 複数のGCMの気候差分のアンサンブル平 均を用いたRCM実験で, 最も起こり得る将来像を予測 する. CMIP-3, A1Bシナリオに基づき21世紀末を予測し た結果，対象計算領域では，2.7度程度の昇温，10\%程 度の降水量増加，15 20\%程度の強雨の増加が予測され た．また，気候差分を特異值分解することで，特定の統 計情報をもった気候差分が作成される，それらの気候差 分をRCM将来気候実験に利用することで，地域スケー ルの将来気候予測の不確実性の幅を見積もることができ る. 対象計算領域では, 0.7 度程度の標準偏差で気温の 不確実性があり，年降水量の変化比では，7～16\%（25 〜75パーセンタイル幅）程度の幅が見積もられた．ただ し，降水量の変化には，気候差分に対寸る非線形応答が 認められたうえ，第2モードまでしか計算していないた め, 不確実性の幅はさらに広がる可能性がある。

本研究では, 地域スケールの気候変化を確率論的に扱 うことができた。一方で，いくつかの課題が残る。下位 モードの実験の必要性，バイアス補正の必要性，正規性 の仮定および非線形応答に対する扱い方の検討，短周期 変動の気候変化の取り扱いに関する研究が必要である.

謝辞 : 本研究は, 文部科学省の気候变動適応研究推進プ ログラム「気候変動に適応する河川・水資源地域管理シ ステムの開発（代表 : 小池俊雄）」，文部科学省の気候 変動適応技術社会実装プログラム「超高解像度ダウンス ケーリング技術の開発（代表 : 石川洋一）」，および科 学技術振興機構のテニュアトラック普及・定着事業の支 援を得た。

\section{参考文献}

1) Intergovernmental Panel on Climate Change (IPCC): Climate Change 2013: The Physical Science Basis. Contribution of Working Group I to the Fifth Assessment Report of the Intergovernmental Panel on Climate Change, edited by Stocker et al., 1535 pp, Cambridge University Press, Cambridge, U.K., 2013.
2) Wilby, R. L., S. P. Charles, E. Zorita, B. Timbal, P. Whetton, L. O. Mearns, Guidelines for use of climate scenarios developed from statistical downscaling methods. 2004.

3) Wakazuki, Y., M. Nakamura, S. Kanada, C. Muroi: Climatological Reproducibility Evaluation and Future Climate Projection of Extreme Precipitation Events in the Baiu Season Using a HighResolution Non-Hydrostatic RCM in Comparison with an AGCM. Journal of the Meteorological Society of Japan, Vol. 86, pp. 951-967, 2008.

4) Sato, T., F. Kimura, A. Kitoh: Projection of global warming onto regional precipitation over Mongolia using a regional climate model. Journal of Hydrology, Vol. 333, pp. 144-154, 2006.

5) Kimura, F., A. Kitoh: Downscaling by pseudo global warning method. The final report of the research project on the impact of climate changes on agricultural production system in arid areas (ICCAP), Research Institute for Humanity and Nature, pp. 43-46, 2007.

6) Misra, V., M. Kanamitsu: Anomaly Nesting: A Methodology to downscale seasonal climate simulations from AGCMs. J. Climate, Vol. 17, pp. 3249-3262, 2004.

7) Tebaldi, C., L. Mearns, D. Nychka, R. Smith: Regional probabilities of precipitation change: A Bayesian analysis of multimodel simulations. Geophys. Res. Lett., Vol. 31, pp. L24213, 2004.

8) Hara, M., T. Yoshikane, H. Kawase, F. Kimura: Estimation of the impact of global warming on snow depth in Japan by the pseudoglobal-warming method. Hydrological Research Letters, Vol. 2, pp. 61-64, 2008.

9) Wakazuki, Y.: Modified relative humidity using the Johnson's $S_{B}$ distribution function. SOLA, Vol. 9, pp. 111-114, 2013.

10) Wakazuki, Y., M. Hara, F. Kimura: A method to treat climate changes of year-to-year variations in the pseudo-global-warming method as a dynamical downscaling. American Geophysical Union 2010 Fall Meeting. San Francisco USA, 2010.

11) Kawase, H., T. Yoshikane, M. Hara, F. Kimura, T. Yasunari, B. Ailikun, H. Ueda, T. Inoue: Intermodel variability of future changes in the Baiu rainband estimated by the pseudo global warming downscaling method, J. Geophys. Res., Vol. 114, pp. D24110, 2009.

12) Wakazuki, Y., R. Rasmussen: Incremental dynamical downscaling for probabilistic analysis based on multiple GCM projections, Geophysical Research Letters, doi: 10.1002/2015GL066242, 2015.

13) Meehl, G. A., C. Covey, T. Delworth, M. Latif, B. McAvaney, J. F. B. Mitchell, R. J. Stouffer, K. E. Taylor (2007), The WCRP CMIP3 multi-model dataset: A new era in climate change research. Bulletin of the American Meteorological Society, Vol. 88, pp. 1383-1394, 2007.

14) Skamarock, W. C., J. B. Klemp, J. Dudhia, D. O. Gill, D. M. Barker, M. G. Duda, X. Y. Huang, W. Wang, J. G. Powers: A description of the Advanced Research WRF Version 3. NCAR Technical Note, Vol. 475, pp. 1-113, 2008.

15) Dee, D. P., et al.: The ERA-Interim reanalysis: Configuration and performance of the data assimilation system. Q. J. R. Meteorol. Soc., Vol. 137, pp. 553-597, 2011.

(2015. 9. 30受付) 